Robert Degen

(Uniwersytet Mikołaja Kopernika w Toruniu)

dr hab., rdegen@umk.pl

ORCID iD: 0000-0003-3467-9341

Krzysztof Syta

(Uniwersytet Mikołaja Kopernika w Toruniu)

drhab., ksyta@umk.pl

ORCID iD: 0000-0002-9466-1525

\title{
Mieczysław Białynia-Rzepecki \\ i Tadeusz Antoni Esman \\ Przyczynek do charakterystyki kadry kierowniczej archiwów państwowych w okresie międzywojennym
}

\section{Uwagi wstępne}

Tworzona od 1917 r. sieć polskich archiwów państwowych łączyła istniejące wcześniej archiwa historyczne i dopiero powstające placówki ${ }^{1}$. Przyjmuje się, że aktem ustanawiającym sieć był dekret Naczelnika Państwa z 7 lutego 1919 r. o organizacji archiwów państwowych i opiece nad archiwaliami, który na liście instytucji archiwalnych wyliczał pięć archiwów warszawskich (Archiwum Główne Akt Dawnych, Archiwum Akt Dawnych, Archiwum Ministerstwa Wyznań Religijnych i Oświecenia Publicznego, Archiwum Wojskowe i Archiwum Skarbowe), Archiwum Państwowe we Lwowie oraz „archiwa miejscowe" w Lublinie, Piotrkowie i Płocku. W końcu 1923 r. liczba archiwów państwowych wzrosła do dwudziestu, a 1 stycznia 1924 r. włączono do sieci Oddział Archiwum Państwowego Poznańskiego w Bydgoszczy². W ten sposób jednym ze 122 pracowników zatrudnionych wówczas w archiwach państwowych został Mieczysław Białynia-Rzepecki, w 1939 r. do nieco

\footnotetext{
${ }^{1}$ Syntetyczne ujęcie historii polskich archiwów państwowych w okresie międzywojennym zob. I. Mamczak-Gadkowska, Archiwa państwowe II Rzeczypospolitej, Poznań 2006.

${ }^{2}$ O genezie archiwum bydgoskiego ostatnio pisali R. Degen, K. Syta, Archiwum byłej Komisji Generalnej dla Wielkopolski i Pomorza w latach 1920-1924. Przyczynek do genezy bydgoskiego archiwum państwowego [w druku].
} 
mniej licznego grona - 113 osób - zaliczał się Tadeusz Esman³. Obaj byli kierownikami bydgoskiej placówki archiwalnej.

Przed podjętymi badaniami postawiliśmy podwójny cel: uzupełnienie biografii obu bydgoskich archiwistów i ukazanie ich na tle środowiska kierowniczego przedwojennych terenowych archiwów państwowych. Przy realizacji pierwszego pomocne były publikowane wcześniej biogramy Białyni-Rzepeckiego i Esmana ${ }^{4}$, choć kwerendą objęliśmy również materiały z zasobów archiwów państwowych w Bydgoszczy i Poznaniu oraz Archiwum Uniwersytetu im. Adama Mickiewicza w Poznaniu 5 . Do naszkicowania portretu środowiska, współtworzonego w latach 1918-1939 przez bydgoskich archiwistów, do którego oprócz nich należało 24 kierowników ${ }^{6}$, wykorzystaliśmy przede wszystkim trzy wydane tomy Słownika biograficznego archiwistów polskich ${ }^{7}$. W Polskim słowniku biograficznym odnaleźliśmy informacje na temat

${ }^{3}$ I. Mamczak-Gadkowska, dz. cyt., s. 128-129.

${ }^{4}$ Białynia-Rzepecki: J. Kutta, Biatynia-Rzepecki Mieczystaw (1962-1927), archiwista, [w:] Bydgoski słownik biograficzny, pod red. J. Kutty, Bydgoszcz 1994, s. 28-29; A. Perlińska, Biatynia-Rzepecki Mieczystaw, [w:] Stownik biograficzny archiwistów polskich (dalej SBAP), t. I: 1918-1984, pod red. M. Bielińskiej, I. Janosz-Biskupowej, Warszawa-Łódź 1988, s. 39-40. Esman: J. Kutta, Essman (Esman) Tadeusz Antoni (1903-1987), historyk, archiwista, działacz społeczny, [w:] Bydgoski stownik biograficzny, s. 43-45; M. Romaniuk, Esman Tadeusz, [w:] SBAP, t. III: 1835-2015, pod red. E. Rosowskiej, Warszawa 2017, s. 70-72; Tadeusz Esman (1903-1987), „Kalendarz Bydgoski na rok $1989^{\prime \prime}$, r. 22, s. 186-187.

${ }^{5}$ Archiwum Państwowe w Bydgoszczy (dalej APB), Akta miasta Bydgoszczy 1559-1945 [1946-1950], seria Zarząd Miejski w Bydgoszczy 1920-1939, Kartoteka ewidencji ludności (dalej KEL); APB, Archiwum Państwowe w Poznaniu Oddział w Bydgoszczy 1924-1939 (dalej APBoB), sygn. 62; APB, Wojewódzkie Archiwum Państwowe w Bydgoszczy [1938] 19451983 (dalej WAPB), sygn. 113, 121; APB, Archiwum dr Anny Perlińskiej dyrektora Archiwum Państwowego w Bydgoszczy [1903] 1921-2005, sygn. 253; APB, Spuścizny i kolekcje rodzinne w Archiwum Państwowym w Bydgoszczy - zbiór szczątków zespołów 1769-2015, sygn. 366; APB, Archiwum zakładowe AP w Bydgoszczy (dalej AzAPB), sygn. 2/54; Archiwum Państwowe w Poznaniu (dalej APP), Akta miasta Poznania 1254-1945 (dalej AmP), sygn. 14385; Archiwum Uniwersytetu im. Adama Mickiewicza w Poznaniu (dalej AUAM), sygn. 103b/577. Za wskazówki wyszukiwawcze w zasobach poznańskich archiwów i za pomoc w dostępie do materiałów serdecznie dziękujemy mgr. Piotrowi Józefiakowi.

${ }^{6}$ Oprócz Białyni-Rzepeckiego i Esmana byli to: Oswald Balzer, Eugeniusz Barwiński, Ludwik Bazylewski, Leon Białkowski, Franciszek Duda, Wacław Gizbert-Studnicki, Józef Julian Głazek, Jerzy Frankenstein, Kazimierz Kaczmarczyk, Ferdynand Krone, Janina Kozłowska-Studnicka, Ryszard Mienicki, Czesław Milewski, Welamin Rutski, Józef Paczkowski, Władysław Prawdzik, Adam Próchnik, Stanisław Ptaszycki, Józef Raciborski, ks. Józef Rokoszny, Ignacy Świątkowski, Marian Witkowski, Stefan Zgliczyński, Zenon Żurakowski. Na liście tej nie ma kierownika archiwum w Suwałkach. Do 1926 r. funkcje jego opiekuna pełnili archiwiści z Łomży, najpierw tamtejszy delegat WAP Jan Witkiewicz, potem kierownik oddziału Władysław Prawdzik, zob. T. Radziwonowicz, O powstaniu i działalności Archiwum Państwowego w Suwałkach (1921-1926), „Rocznik Augustowsko-Suwalski” 2006, t. 6, s. 65-75.

${ }^{7}$ Por. przypis 4. M. Bielińska, Balzer Oswald, [w:] SBAP, t. I, s. 29-30; A. Kamiński, Barwiński Eugeniusz, [w:] SBAP, t. I, s. 34-36; R. Guldon, Bazylewski Ludwik, [w:] SBAP, t. II: 1906-2001, pod red. B. Woszczyńskiego, Warszawa 2002, s. 32-33; F. Cieślak, Białkowski Leon, [w:] SBAP, t. I, 
Wacława Gizberta-Studnickiego ${ }^{8}$, a notki poświęcone płockim archiwistom Jerzemu Frankensteinowi i Stanisławowi Zgliczyńskiemu - w II tomie wydawnictwa pt. Płocczanie znani i nieznani. Słownik biograficzny9. Mimo wysiłków, nie udało się nam odnaleźć informacji biograficznych na temat dwóch archiwistów związanych z archiwami w Kielcach i Radomiu, Ferdynanda Krone i Zenona Żurakowskiego ${ }^{10}$.

\section{Mieczysław Białynia-Rzepecki}

Mieczysław Białynia-Rzepecki urodził się 5 stycznia 1862 r. we wsi Sławno, leżącej wówczas w powiecie czarnkowskim (obecnie gnieźnieńskim). Jego rodzicami byli Franciszek i Teofila z Sikorskich ${ }^{11}$. Matka w przeciwieństwie do ojca Mieczysława nie miała szlacheckiego pochodzenia. Najprawdopodobniej ich najstarszy syn ochrzczony został w kościele parafialnym pw. św. Mikołaja w Sławnie. Zapewne też krótko po narodzinach Mieczysława jego rodzice przeprowadzili się w okolice Ryczywołu. Wiadomo, że Franciszek był w tym czasie właścicielem ziemskim i jednocześnie ekonomem, zapewne w jakimś pobliskim majątku. W kwietniu 1865 r. Rzepeckim urodził się drugi syn, Zygmunt Zdzisław, który zmarł w pół roku później ${ }^{12}$. W kolejnych latach Rzepeckim urodziły się jeszcze trzy córki, w 1868 r. Nepomucena Honorata,

s. 37-39; A. Kamiński, Duda Franciszek, [w:] SBAP, t. I, s. 56-57; R. Guldon, Głazek Józef Lucjan, [w:], SBAP, t. II, s. 54; I. Radtke, Kaczmarczyk Kazimierz, [w:] SBAP, t. I, s. 93-95; J. Karwasińska, Kozłowska-Studnicka Janina, [w:] SBAP, t. I, s. 114-116; A. Tomczak, Mienicki Ryszard, [w:] SBAP, t. I, s. 144-146; M. Sierocka-Pośpiech, Milewski Czestaw, [w:] SBAP, t. III, s. 153-154; T. Piekarski, Rutski Welamin Stefan, [w:] SBAP, t. III, s. 209; I. Mamczak-Gadkowska, Paczkowski Józef, [w:] SBAP, t. I, s. 161-164; H. Kisiel, Prawdzik Wtadystaw, [w:] SBAP, t. I, s. 174-175; R. Kotewicz i red., Próchnik Adam Feliks, [w:] SBAP, t. II, s. 149-151; M. Trojanowska, Ptaszycki Stanisław, [w:] SBAP, t. I, s. 178-180; J. Wasiak, Raciborski-Rawita Józef, [w:] SBAP, t. I, s. 183-184; W. Wójcik, Rokoszny Józef ks., [w:] SBAP, t. I, s. 185-186; R. Kotewicz i red., Świątkowski Ignacy, [w:] SBAP, t. II, s. 182; E. Szczepaniak, Witkowski Marian, [w:] SBAP, t. II, s. 193.

${ }^{8}$ M. Ryńca, W. Suleja, Studnicki (Gizbert-Studnicki) Wactaw, [w:] Polski stownik biograficzny, t. 45, pod red. nacz. A. Romanowskiego, Warszawa-Kraków 2007, s. 121-125.

${ }^{9}$ J. Papierowski, J. Stefański, Płocczanie znani i nieznani. Stownik biograficzny, t. II, Płock 2007, s. 151, 724.

${ }^{10}$ Publikowane świętokrzyskie słowniki biograficzne zamykają się na okresie wcześniejszym. Kwerendą objęliśmy opracowania: A. Makowska, B. Ryszewski, Zarys dziejów Archiwum Państwowego w Kielcach (Z okazji czterdziestolecia), „Archeion” 1963, t. 39, s. 45-62; I. Pogorzelska, 90 lat Archiwum Państwowego w Kielcach, "Z Dziejów Miasta i Regionu. Rocznik Oddziału PTH w Skarżysku-Kamiennej" 2014, r. 5, s. 83-106; tejże, Historia Archiwum Państwowego w Kielcach, „Świętokrzyskie Studia Archiwalno-Historyczne” 2012, t. 1, s. 17-34.

${ }^{11}$ J. Kutta, Białynia-Rzepecki, s. 28-29.

12 Biblioteka Kórnicka PAN, Teki Dworzaczka, reg. 59315 i 59330, http://teki.bkpan.po znan.pl/index_regesty.html (dostęp: 25.09.2019). 
w 1870 r. Wanda, w 1871 r. Elżbieta ${ }^{13}$. Tak więc w dzieciństwie i wczesnej młodości Mieczysława otaczały w środowisku rodzinnym zapewne głównie kobiety i ",kobietki".

Prawie nic nie wiemy o edukacji Mieczysława Białyni-Rzepeckiego. Jeśli przyjąć za Perlińską, że ukończył on szkoły w Bydgoszczy, musiał być absolwentem tamtejszego Königliches Friedrich-Wilhelm-Gymnasium (Królewskiego Gimnazjum Fryderyka Wilhelma III) ${ }^{14}$. Do 1883 r. była to jedyna szkoła średnia w Bydgoszczy, która pozwalała zdobyć maturę ${ }^{15}$, a to właśnie egzamin dojrzałości otwierał w Prusach młodym ludziom drzwi do kariery uniwersyteckiej i - co w przypadku Białyni-Rzepeckiego ważniejsze - urzędniczej $^{16}$. Wiadomo jednak, że w 1880 r. odbywał on jednoroczną służbę wojskową $\mathrm{w}$ artylerii ${ }^{17}$.

O tym, że musiał przejść przynajmniej przez kilka poziomów nauczania, świadczyć może fakt podjęcia przez niego, nie wiemy jednak kiedy, pracy w Königliche Preussische Generalkommission für die Provinzen Westpreussen und Posen, utworzonej przez władze pruskie w 1832 r. Celem jej działania było: wsparcie procesu uwłaszczenia i regulacji stosunków włościańskich w Wielkim Księstwie Poznańskim, przeprowadzenie reformy rolnej oraz likwidacja poddaństwa chłopów we wschodnich częściach Królestwa Prus. Być może praca w Komisji Generalnej nie była jego pierwszą posadą. Trudno powiedzieć, jak wyglądały stopnie awansu zawodowego Białyni-Rzepeckiego. Na pewno jednak pracował jako zarządca Archiwum byłej Komisji Generalnej w Bydgoszczy (AKG) i sekretarz generalny już w roku $1909^{18}$.

Zapewne podejmując pracę w bydgoskiej Komisji Generalnej, Białynia-Rzepecki był już żonaty z Pelagią Nehring ${ }^{19}$. Miejsce urodzenia żony Mieczysława, Runowo Krajeńskie, wskazywałoby na związek z zamożną rodziną Nehringów posiadającą $w$ tym rejonie spore majętności, m.in. pałac wSuchorączku. Być może to właśnie małżeństwo Mieczysława z Nehringówną

13 Tamże, reg. 59316, 59317 i 59319, http://teki.bkpan.poznan.pl/index_regesty.html (dostęp: 25.09.2019).

${ }^{14}$ Por. E. Małachowski, Królewskie Gimnazjum Fryderyka Wilhelma, [w:] Encyklopedia Bydgoszczy, t. 2, red. W. Jastrzębski, Bydgoszcz 2017, s. 301-302.

${ }^{15} \mathrm{~W} 1883$ r., gdy Białynia-Rzepecki był już zapewne po maturze, powstało w Bydgoszczy gimnazjum realne, przekształcone z działającej tam wcześniej szkoły realnej. Por. E. Machowski, Miejskie Gimnazjum Realne, [w:] Encyklopedia Bydgoszczy, s. 311.

${ }^{16}$ J. Kwiatek, Spór o model gimnazjum w XIX-wiecznej niemieckiej myśli pedagogicznej, „Cieszyński Almanach Pedagogiczny" 2012, nr 1, s. 57.

${ }^{17}$ APB, APBoB, sygn. 62, s. 3.

${ }^{18}$ J. Kutta, Białynia-Rzepecki, s. 28.

${ }^{19}$ Kutta w biogramie Białyni-Rzepeckiego podaje błędnie, że jego żona nosiła imię Paulina, zob. J. Kutta, Białynia-Rzepecki, s. 28. Pelagia Franciszka Nehring urodziła się 26 grudnia 1860 r. w Runowie pow. Wyrzysk. Jej rodzicami byli Walerian i Paulina z domu Musolf, zob. APB, KEL. 
ułatwiło mu podjęcie pracy w bydgoskiej Komisji Generalnej. Rzepeccy mieli dwóch synów - Leona i Ludwika Mieczysława ${ }^{20}$.

We wrześniu 1914 r. Białynia-Rzepecki zgłosił się jako ochotnik do armii pruskiej. Tłumacząc swoją decyzję, wspominał: „Biorąc pod uwagę, że jestem już przeznaczony za urzędnika biurowego do intendentury i możliwość uratowania syna mego od śmierci wstąpiłem dnia 14.08.1914 r. jako ochotnik wojenny $w$ randze chorążego do Erste Batalion Fussartillerie Regiment $15 \mathrm{w}$ Grudziądzu"21. Obowiązki kierownika AKG przekazał inżynierowi Wilhelmowi Heidelkowi.

Okres służby wojskowej w przypadku Mieczysława Rzepeckiego obfitował $\mathrm{w}$ wiele perypetii opisanych przez niego ze szczegółami we wspomnieniach $^{22}$. Tutaj tylko nadmienić można, że do maja 1919 r. szkolił rekrutów w Grudziądzu, w tym też czasie awansowano go do stopnia podporucznika. Od maja do lipca 1915 r. służył w Munsterwalde, dzisiaj Opalenie w gm. Gniew, gdzie szkolił żołnierzy baterii artylerii przeciwlotniczej, a następnie przerzucono go do Janowa (dzisiaj w pow. nidzickim), gdzie pełnił funkcję komendanta miasta i placówki kolejowej. Późną jesienią roku 1915 oddział Białyni-Rzepeckiego został przerzucony na wschód i stacjonował we wsi Sabielewszy leżącej między Iwiem a Jaruczyszkami (dzisiaj obwód grodzieński). W wyniku obrażeń, jakie Białynia-Rzepecki odniósł w trakcie budowy stanowiska obserwacyjnego nad Berezyną, wczesną wiosną 1916 r. trafił do szpitala, a po rekonwalescencji zaproponowano mu objęcie funkcji naczelnika biura w urzędzie powiatowym (Kreisamt) w Ostrowi (obecnej Ostrowi Mazowieckiej). Udał się tam w połowie kwietnia tego roku. Jak wspominał „zarazem mianowano mnie zastępcą burmistrza Ostrowa i zastępcą sędziego pokoju" ${ }^{23}$. Białynia-Rzepecki na nowym stanowisku bardzo szybko zorganizował pracę podległego mu urzędu, wykazując się dużym zmysłem organizacyjnym: „Otoczyłem się zaraz kilku doskonałymi pracownikami biurowymi, którzy byli z zawodu sekretarzami wzgl. kierownikami biur adwokackich i po większej części Polakami" 24 .

W kilka dni po oficjalnym zawieszeniu broni kończącym I wojnę światową, dokładnie 20 listopada 1918 r. Białynia-Rzepecki objął ponownie kierownictwo w pruskim jeszcze AKG. Bydgoszcz, tak jak cała Wielkopolska i Pomorze Nadwiślańskie, formalnie znajdowała się jeszcze w tym czasie pod

${ }^{20}$ Co prawda Kutta w biogramie Białyni-Rzepeckiego wspomina tylko o Ludwiku Romanie Mieczysławie, urodzonym w 1905 r. w Bydgoszczy, to we wspomnieniach bydgoskiego archiwisty pojawia się syn Leon, który w momencie wybuchu I wojny światowej miał osiemnaście i pół roku, tak więc musiał urodzić się około roku 1895, zob. APB, APPoB, sygn. 62, s. 1.

${ }^{21}$ Tamże, s. 2 nlb.

${ }^{22}$ Tamże.

${ }^{23}$ Tamże, s. 9.

${ }^{24}$ Tamże. 
administracją niemiecką. Powracając po I wojnie światowej do Bydgoszczy, Białynia-Rzepecki mocno zaangażował się w działalność narodowo-patriotyczną zmierzającą do przejęcia w mieście władzy przez Polaków. Między innymi 20 lipca 1919 r. przy dużym jego udziale doszło do utworzenia w Bydgoszczy Towarzystwa Urzędników Polskich, do którego przystąpiło około pięćset osób ${ }^{25}$. Stąd też z dużymi problemami Białynia-Rzepecki jako prezes Towarzystwa zaczął organizować dla jego członków kursy języka polskiego, które prowadzono do końca stycznia roku 1920, tzn. do momentu wkroczenia do Bydgoszczy Wojska Polskiego i zaprowadzenia polskiej administracji. Od stycznia 1920 r. Rzepecki stał również na czele Straży Obywatelskiej zabezpieczającej ład i porządek w mieście, m.in. organizował i zabezpieczał wejście do Bydgoszczy wojsk polskich 20 stycznia 1920 r. i przyjazd do miasta dwa dni później gen. Józefa Dowbora-Muśnickiego $^{26}$.

Od początku lutego 1920 r. na polecenie Ministerstwa byłej Dzielnicy Pruskiej Białynia-Rzepecki zaczął organizować Komisję Generalną i Bank Rentowy w Poznaniu, by krótko później przenieść je do Bydgoszczy, do budynku przy ul. Dworcowej 29. Sprawował wówczas funkcję dyrektora byłej Komisji Generalnej. W 1922 r. (według Rzepeckiego w 1923 r.), w wyniku likwidacji Ministerstwa b. Dzielnicy Pruskiej, Komisja Generalna i Bank Rentowy zostały podporządkowane Okręgowemu Urzędowi Ziemskiemu w Poznaniu. Ostatecznie od 1 stycznia 1924 r. AKG zostało przekształcone w Oddział Archiwum Państwowego Poznańskiego w Bydgoszczy (OAPPwB), którego kierownikiem został Białynia-Rzepecki. Bank Rentowy przekształcono wówczas w Wydział Rent byłych Banków Rentowych w Bydgoszczy, podlegający poznańskiemu Oddziałowi Państwowego Banku Rolnego ${ }^{27}$.

Białynia-Rzepecki pozostawał na stanowisku kierownika OAPPwB do śmierci, tzn. do 9 listopada $1927 \mathrm{r} .{ }^{28}$

Ze względu na ograniczenia źródłowe trudno w szczegółach ocenić pracę Rzepeckiego jako kierownika bydgoskiego archiwum. Zapewne przed $1924 \mathrm{r}$. jako kierownik AKG w latach 1920-1923 uczestniczył we wszystkich pracach, jakie wymienił w sprawozdaniu złożonym 13 lutego 1927 r., na kilka miesięcy przed śmiercią, do Wydziału Archiwów Państwowych (WAP). Personel pod jego kierownictwem zajmował się układaniem akt, map i książek AKG, urządzaniem biur Archiwum i Banku Rentowego, który przeniesiono do Bydgoszczy z Poznania. Przeniesienie Banku Rentowego do Bydgoszczy spowodowało proces przejmowania do placówki kierowanej przez Rzepeckiego

\footnotetext{
${ }^{25}$ Tamże, s. 12 i nn.

${ }^{26}$ Tamże, s. 16.

${ }^{27}$ APB, APPoB, sygn. 62, s. 16-17 nlb.

${ }^{28}$ A. Perlińska, dz. cyt., s. 40.
} 
akt z kas skarbowych i urzędów katastralnych. Dużo pracy wkładano w tym czasie w wymianę archiwaliów z władzami niemieckimi, a także opracowywanie rejestrów spraw niezałatwionych w związku z brakiem dokumentacji je obrazujących, znajdującej się nadal w rękach urzędów niemieckich bądź polskich. Załatwiano oczywiście w tym czasie również corocznie po kilka tysięcy spraw wnoszonych do AKG i Banku Rentowego. Spraw, które często wymagały skomplikowanej, ze względu na nieuporządkowany w pełni zasób archiwalny, procedury kwerendalnej ${ }^{29}$. Na ile Białynia-Rzepecki w latach 1924-1927 angażował się w prace o charakterze ściśle archiwalnym, a na ile w działalność o urzędniczym, trudno jednoznacznie stwierdzić. Wydaje się, że dużo bardziej angażował się w bieżącą działalność kierowanego przez siebie archiwum aniżeli zawiłe prace archiwalne. Można tak wnioskować w oparciu o przedstawiane przez niego WAP okresowe sprawozdania, w których zdecydowanie najwięcej miejsca poświęcał bieżącym sprawom, wnoszonym do archiwum przez osoby prywatne i instytucje. W przeważającej większości były to podania o wystawienie różnego rodzaju zaświadczeń. Warto w końcu wspomnieć, że i sam Białynia-Rzepecki postrzegał bydgoskie archiwum bardziej jako urząd aniżeli historyczne archiwum ${ }^{30}$.

W przeciwieństwie do informacji w zakresie szczegółowych prac wykonywanych w bydgoskim archiwum w okresie kierownictwa Białyni-Rzepeckiego dużo więcej wiadomo na temat warunków lokalowych, wyposażenia archiwum w sprzęty oraz jego zasobu. Zostały one szczegółowo opisane w protokole zdawczo-odbiorczym, jaki sporządzono w dniach 25/26 stycznia 1924 r. w Bydgoszczy przy przejmowaniu budynku, inwentarza, akt, map i biblioteki pozostałych po AKG przez dr. Kazimierza Kaczmarczyka reprezentującego ministra wyznań religijnych i oświecenia publicznego (MWRiOP) ${ }^{31}$. Zarówno stan budynku, jak i jego wyposażenie pozostawiały wiele do życzenia. Na zasób archiwum składały się: akta spraw uwłaszczeniowych z lat 1796-1924 w liczbie około dwustu tys. fascykułów i tomów oraz dziewięciu tys. map. Zbiory biblioteki archiwum, liczącej 2230 tomów książek prawniczych, ekonomicznych i statystycznych z XVIII-XIX w., przechowywano w ośmiu szafach. Zasób bydgoskiego archiwum bardzo szybko, bo już w lipcu 1924 r. powiększył się o szesnaście tys. fascykułów akt rejencji bydgoskiej z lat 1815-1916 przewiezionych na szesnastu wozach z budynku Rejencji

${ }^{29}$ AB, APPoB, sygn. 4a, s. 203-205.

${ }^{30}$ Opinię taką zawarł Białynia-Rzepecki w tekście poświęconym historii bydgoskiego archiwum, jaki miał ukazać się w pierwszym tomie czasopisma archiwalnego „Archeion” wydawanego od 1927 r. przez WAP. Ostatecznie tekst ten nie został opublikowany, zob. APB, APPoB, sygn. 4a, s. 183.

${ }^{31} \mathrm{APB}, \mathrm{APPoB}$, sygn. 3, s. 156 i nn. 
Bydgoskiej ${ }^{32}$. Wiadomo jednak, że opracowywanie tych akt rozpoczęto dopiero w roku 1927, a więc roku śmierci Białyni-Rzepeckiego.

Poważnym problemem, z jakim borykał się Białynia-Rzepecki jako kierownik bydgoskiego archiwum, był brak personelu. Do momentu przejęcia AKG przez WAP Białyni-Rzepeckiemu podlegało kilkunastu pracowników, którzy dzielili się swoimi obowiązkami, wykonując, z racji charakteru instytucji, w jakiej pracowali, zadania tak urzędowe, jak i archiwalne ${ }^{33}$. Od początku 1924 r. personel OAPPwB składał się tylko z dwóch osób, tzn. kierownika oraz woźnego Antoniego Błaszkowskiego, przyjętego do pracy w maju 1924 r. Jak wynika z prośby złożonej w sierpniu 1924 r. przez Białynię-Rzepeckiego do Archiwum Państwowego w Poznaniu (APP) o zgodę na zatrudnienie pracowników merytorycznych, natłok pracy zmusił kierownika archiwum do przyuczenia Błaszkowskiego w zakresie maszynopisania. Ten z kolei wykonywał prace biurowe ze szkodą dla swoich etatowych obowiązków woźnego. Oczywiście, taka sytuacja na dłuższy czas była nie do przyjęcia, stąd prośba $\mathrm{o}$ „przyjęcie najmniej jednego funkcjonariusza do wykonywania prac biurowych i archiwalnych etc." ${ }^{34}$ Mimo poparcia prośby Białyni-Rzepeckiego przez jego bezpośredniego zwierzchnika, tzn. Kazimierza Kaczmarczyka, dyrektora APP, brak środków budżetowych stanowił koronny argument ze strony WAP w odmowie prośbie kierownika bydgoskiego archiwum ${ }^{35}$.

Nie tylko kwestie kadrowe spędzały sen z powiek Białyni-Rzepeckiemu jako kierownikowi archiwum. Innym palącym problemem była konieczność uzyskania środków finansowych na remont budynku archiwalnego, w którym archiwalia nie miały dostatecznego zabezpieczenia. Szczególnie pilnym problemem do rozwiązania była naprawa dachu. W końcu warto wspomnieć o zmaganiach Białyni-Rzepeckiego w celu zachowania stanu posiadania pomieszczeń na potrzeby archiwalne. Świadczy o tym m.in. zachowana ko-

32 Tamże, s. 173; Archiwum Państwowe w Poznaniu w latach 1919-1926, Kronika, pod red. W. Łopacińskiego, „Archeion” 1928, t. 4, s. 150.

${ }^{33}$ Sprawozdania Białyni-Rzepeckiego w zakresie ruchu kadrowego, zob. APB, APPoB, sygn. 4 a.

${ }^{34}$ APB, APPoB, sygn. 11, s. 286.

${ }^{35}$ W piśmie z 11 listopada 1924 r. adresowanym do APP ówczesny kierownik WAP Józef Paczkowski w sprawie prośby Rzepeckiego o zwiększenie etatów w jego archiwum napisał: „W sprawie powiększenia personału w Oddziale Bydgoskim Wydział Archiwów Państwowych oświadcza, że nie jest ono możliwe, ponieważ w tej chwili Wydział Archiwów Państwowych nie rozporządza żadnym wolnym etatem, który można by było przenieść do Oddziału Bydgoskiego. Wydział Archiwów Państwowych zaznacza, że stan personalny Oddziału Bydgoskiego był ustalony przez dawniejszą władzę przełożoną tego urzędu, niezależnie od Ministerstwa Wyznań Religijnych i Oświecenia Publicznego, jako naczelnej władzy przejmującej Archiwum Bydgoskie. Ustalenie to zaś nastąpiło w czasie obowiązujących rygorów oszczędnościowych, nie dopuszczających zwiększenia etatów personalnych. Wydział uznaje w zupełności trudne warunki pracy, lecz nie [jest] jeszcze władny ich usunąć". Tamże, s. 294 nlb. 
respondencja z 1924 r. w sprawie przekazania na potrzeby Powiatowego Urzędu Ziemskiego w Bydgoszczy kolejnych dwóch pomieszczeń, dotychczas wykorzystywanych przez bydgoskie archiwum ${ }^{36}$.

\section{Tadeusz Antoni Esman}

Następca Białyni-Rzepeckiego, Tadeusz Antoni Esman, był młodszy od poprzednika o 41 lat $^{37}$. Urodził się 12 czerwca 1903 r. w Poznaniu ${ }^{38}$. Pochodził z rodziny o tradycjach patriotycznych. Co prawda jego ojciec Józef August był poznańskim rzeźnikiem i nic nie wiadomo o jego politycznym zaangażowaniu, jednak dziadek brał udział w powstaniu 1848 r. ${ }^{39}$ Tadeusz jako uczeń był członkiem polskiego harcerstwa i szkolnych organizacji niepodległościowych, a w czasie powstania wielkopolskiego gońcem głównej kwatery władz powstańczych, później Komendy Miasta Poznania.

Szkołę średnią - poznańskie gimnazjum Bergera - ukończył Esman w 1923 r. ${ }^{40}$ i rozpoczął studia historyczne na Wydziale Filozoficznym Uniwersytetu Poznańskiego. Po zmianach organizacyjnych w Uniwersytecie kontynuował je na Wydziale Humanistycznym nieprzerwanie do 1928 r. ${ }^{41}$ Był uczestnikiem seminariów prof. Kazimierza Tymienieckiego i prof. Adama Skałkowskiego ${ }^{42}$. Działał w ruchu studenckim i reprezentował środowisko poznańskie w czasie ogólnopolskiego zjazdu historyków studentów, który odbył się w Wilnie na początku listopada 1925 r. ${ }^{43}$ Miesiąc później uczestniczył

${ }^{36}$ Akta spraw dotyczących remontów i problemów lokalowych bydgoskiego archiwum, zob. APB, APPoB, sygn. 39.

${ }^{37}$ Część faktów biograficznych z życia Esmana na podstawie trzech publikowanych biogramów. Por. przyp. 4.

${ }^{38} \mathrm{~W}$ poznańskiej ewidencji ludności figuruje jako „Thaddaus Anton Essmann”. APP, AmP, sygn. 14385, s. 250. Kopie karty można odnaleźć w serwisie "szukajwarchiwach.pl”, zob. https://szukajwarchiwach.pl/53/474/0/19.3/14385/str/1/18/15/-cOBXyFmGfMbx3 GKDiP81Q/\#tabSkany (dostęp: 12.01.2019).

${ }^{39} \mathrm{~W}$ dwóch wspomnianych wcześniej biogramach Esmana (z kalendarza i bydgoskiego słownika) pojawia się informacja, że w działalność niepodległościową zaangażowana była także siostra Esmana, Ewa, uczestniczka strajków szkolnych w latach 1905-1907. Jednak w ewidencji ludności Poznania jedynymi dziećmi Józefa Augusta Esmana i Tekli (ze Śmidowiczów) byli Tadeusz i Stefan (zm. 18 sierpnia 1905 r.). Por. APP, AmP, sygn. 14385, s. 250.

${ }^{40} \mathrm{APB}, \mathrm{AzAPB}$, sygn. 2/54, s. 234.

${ }^{41}$ W życiorysach Esman twierdził, że przed przerwą studiował w latach 1923-1927, por. m.in. tamże, s. 2, natomiast $\mathrm{w}$ aktach uniwersyteckich jako rok przerwania studiów widnieje 1928, AUAM, sygn. 103b/577.

${ }^{42} \mathrm{APB}, \mathrm{AzAPB}$, sygn. 2/54, s. 234.

${ }^{43}$ Krótką informację o zjeździe zob. A. Deruga, Sprawozdanie z działalności Koła Historyków Stuchaczy USB w Wilnie w latach 1923-1933, [w:] Księga pamiątkowa Koła Historyków Stuchaczy Uniwersytetu Stefana Batorego w Wilnie 1923-1933, Wilno 1933, s. 357. 
w poznańskim IV Powszechnym Zjeździe Historyków Polskich. Przyznawał się do udziału w organizacji spotkania ${ }^{44}$, choć nie był członkiem zjazdu, a zapewne jednym z 64 „hospitantów” ${ }^{45}$. Zgodnie z regulaminem nie mógł zabierać głosu, stąd trudno stwierdzić, której części obrad się przysłuchiwał. Możliwe, że brał udział w posiedzeniach bliskiej jego zainteresowaniom naukowym Sekcji III, zajmującej się problemami ówczesnej historii najnowszej. Niewykluczone, że przynajmniej raz pojawił się na obradach Sekcji VII, kiedy dyskutowano problematykę uniwersyteckiego kształcenia historyków ${ }^{46}$. Mimo iż Esman był studentem zaangażowanym, przerwał studia z powodów materialnych i sfinalizował dopiero $\mathrm{w}$ połowie lat $30 . \mathrm{XX} \mathrm{w} \cdot{ }^{47}$ Dyplom magistra filozofii w zakresie historii wystawiono mu 15 grudnia 1936 r. ${ }^{48}$ Podstawą do nadania stopnia była praca pt. Jan Wilhelm Kassyusz. Zarys biografii na tle życia Wielkopolski w pierwszej połowie XIX wiek ${ }^{49}$ - jak się wydaje - rozszerzona wersja artykułu o tym tytule, który został wydany już w 1926 r. ${ }^{50}$

Archiwistyczną przygodę Esman rozpoczął długo przed ukończeniem studiów ${ }^{51}$. W lutym 1927 r. zdecydował się przyjąć półroczny kontrakt na porządkowanie zespołu rejencji bydgoskiej. Wtedy pierwszy raz przyjechał do Bydgoszczy. To jego prace doprowadziły do powstania katalogu kartkowego dla generaliów szkolnictwa, akt personalnych i częściowo materiałów registratury policyjnej. Ułożył także alfabetycznie akta szkolne i kościelne miejsco-

\footnotetext{
${ }^{44}$ APB, WAPB, sygn. 121, nlb., Życiorys.

${ }^{45}$ Wykaz członków IV. Powszechnego Zjazdu Historyków Polskich w Poznaniu w dniach od 6 do 8 grudnia 1925 r., [w:] Pamiętnik IV Powszechnego Zjazdu Historyków Polskich w Poznaniu 6-8 grudnia 1925 r. Protokoty, wyd. K. Tyszkowski, Lwów 1927, s. 252.

46 Sekcja VII. Nauczanie historii, [w:] Pamiętnik IV ... Protokoty, s. 147-152. Reformie studiów uniwersyteckich na wydziałach humanistycznych poświęcony był wileński zjazd studentów historyków, w którym - jak wspomniano wcześniej - Esman uczestniczył. Por. A. Deruga, dz. cyt., s. 252.

${ }^{47} \mathrm{~W}$ różnych wersjach życiorysu, także w publikowanych wspomnieniach, Esman podaje różne lata ukończenia studiów: rok 1934, 1935 i 1936, por. Tadeusza Esmana wspomnienia o Bydgoszczy, cz. 1, wybór i oprac. J. Esman, M. Romaniuk, „Kronika Bydgoska” 2007, t. 29, s. 429; APB, AzAPB, sygn. 2/54, s. 2, 24, 234.

${ }^{48}$ AUAM, sygn. 103b/577. Odpis dyplomu zob. m.in.: APB, WAPB, sygn. 121, nlb., Dyplom magistra filozofii (odpis $\mathrm{z}$ odpisu).

${ }^{49}$ AUAM, sygn. 103b/577.

${ }^{50}$ T. Esman, Jan Wilhelm Kassyusz. Zarys biografii na tle życia Wielkopolski w pierwszej połowie XIX wieku, „Strażnica Zachodnia” 1926, r. 5, nr 1, s. 28-61. Publikację tę można także odnaleźć jako samodzielną odbitkę z serii Życiorysy zastużonych Polaków XVIII i XIX wieku (Poznań 1926). O kontynuowaniu badań nad biografią Kassyusza, które mogły znaleźć odzwierciedlenie w pracy magisterskiej, przekonuje kolejny artykuł poświęcony Wielkopolaninowi, opublikowany przez Esmana w 1938 r., tegoż, Uzupetnienie życiorysu Jana Wilhelma Kassyusza, „Kronika Miasta Poznania" 1938, r. 16, nr 2, s. 186-199.

${ }^{51}$ Tadeusza Esmana wspomnienia, s. 429.
} 
wości byłej Rejencji Bydgoskiej52. Po wypełnieniu zobowiązań kontraktowych wrócił do Poznania i kolejne pół roku spędził zatrudniony w Biurze Historycznym Dowództwa Okręgu Korpusu nr VII w Poznaniu, gdzie porządkował materiały dotyczące powstania wielkopolskiego.

Nie było dane Esmanowi na stałe związać się z wojskową służbą historyczną. W poznańskim archiwum państwowym musiał zostawić po sobie na tyle dobre wspomnienie, że już w grudniu 1927 r. wrócił nad Brdę na stałe z nominacją na stanowisko „prowizorycznego kierownika Oddziału Archiwum Państwowego w Bydgoszczy"53. Pozostał tam do początku września 1939 r. a jego status - p.o. kierownika bydgoskiego oddziału - nie uległ zmianie.

Praca Esmana w archiwum bydgoskim była bardzo intensywna. Tylko w 1928 r. kontynuował porządkowanie akt byłej rejencji bydgoskiej (uporządkował 2868 woluminów), inwentaryzował akta byłej Komisji Generalnej dotyczące miejscowości położonych w tym czasie poza granicami Polski i poprawiał katalogi archiwalne. Na potrzeby Okręgowego Urzędu Ziemskiego opracował wykaz włości rentowych w Poznańskiem i na Pomorzu. Zrealizował 117 kwerend pisemnych i ustnych, wyszukał dokumentację oraz umożliwił sporządzenie 49 odrysów planów i 22 odpisów innych dokumentów. Przygotował i wypożyczył urzędom 422 tomy akt i 10 map, w pracowni przyjął 35 użytkowników. Do zasobu archiwum przejął materiały powiatowych kas skarbowych województwa poznańskiego (645 woluminów) i akta okręgowych komisji wyborczych wyborów do sejmu z 1922 r. Poza tym zinwentaryzował majątek ruchomy archiwum ${ }^{54}$.

Biorąc pod uwagę tak duże obciążenie, nie może dziwić niewielka aktywności naukowa Esmana przed wybuchem II wojny światowej. Jak wspomnieliśmy wcześniej, studiując, zaangażował się w studencki ruch naukowy i uczestniczył w organizacji poznańskiego zjazdu historyków polskich. Już w Bydgoszczy był jednym z założycieli tamtejszego Oddziału PTH i członkiem jego zarządu. Zbierał materiały źródłowe do badań nad wielkopolskimi ruchami społecznymi w połowie lat 40 . XIX w., w które był zaangażowany jego dziadek. Niemniej jedynymi opublikowanymi wówczas przez Esmana pracami naukowymi były dwa artykuły poświęcone Janowi Wilhelmowi Kassyuszowi ${ }^{55}$.

Na początku września 1939 r., zgodnie z otrzymanymi poleceniami, Esman starał się ewakuować zasób bydgoskiego archiwum na Wołyń, do

${ }^{52}$ Zakres prac przeprowadzonych najprawdopodobniej przez Esmana na podstawie sprawozdania archiwów państwowych za rok 1927. Zob. Sprawozdanie z działalności archiwów państwowych. Rok 1927, red. W. Łopaciński, „Archeion” 1929, t. 5, s. 44 (Działu Urzędowego).

53 Tadeusza Esmana wspomnienia, s. 429.

${ }^{54}$ Sprawozdanie z działalności archiwów państwowych Rok 1928, red. W. Łopaciński, „Archeion” 1930, t. 6-7, s. 31, 41-42, 55 (Działu Urzędowego).

${ }^{55}$ Por. przypis 50. 
Łucka. Dotarł jedynie do Warszawy i tam pełnił obowiązki administratora budynku zajmowanego wówczas przez Archiwum Główne Akt Dawnych i WAP. Po kapitulacji wyjechał ze stolicy, by - po poszukiwaniu rozproszonej we wrześniu rodziny i miejsca do osiedlenia - ostatecznie wrócić do Bydgoszczy. W styczniu 1940 r. został zatrudniony jako archiwista i tłumacz w Urzędzie Kultury Rolnej. Na kilka miesięcy, od jesieni 1941 r., został wydelegowany do swojego przedwojennego archiwum - wówczas bydgoskiego oddziału Archiwum Rzeszy w Gdańsku - by opracować repertorium map pruskiej komisji generalnej. Koniec wojny przeżył na przymusowych robotach w obozie pod Aleksandrowem Kujawskim, z którego uciekł w połowie stycznia $1945 \mathrm{r} .{ }^{56}$

Po wojnie wrócił do Bydgoszczy i tamtejszego archiwum, początkowo na stanowisko zajmowane tam od 1927 r., czyli "prowizorycznego kierownika” oddziału. Po przekształceniu archiwum w samodzielną placówkę, w 1947 r. powierzono mu funkcję "prowizorycznego dyrektora”, którą pełnił do roku 1952. Złożył z niej rezygnację, jednak w archiwum pozostał do 1970 r., najpierw jako kustosz, potem adiunkt naukowo-badawczy.

Czas powojenny sprzyjał aktywności naukowej Esmana, zarówno w sferze organizacyjnej, jak i badawczej. Od 1948 r. przewodniczył Kołu Związku Bibliotekarzy i Archiwistów w Bydgoszczy, dziesięć lat później stanął na czele Komitetu Organizacyjnego Bydgoskiego Towarzystwa Naukowego. Kontynuował badania historyczne zainicjowane przed wojną. W 1947 r. ukazał się w dwóch częściach jego artykuł pt. Bydgoszcz na tle wypadków $1846 r .^{57}$, rok później biogram dziadka napisany dla Polskiego stownika biograficznego ${ }^{58}$. Owocem zainteresowania przeszłością Bydgoszczy był krótki tekst w pracy zbiorowej poświęconej temu miastu ${ }^{59}$ i dwie edycje źródłowe: wydane z Zenonem Guldonem Statuty i przywileje cechów bydgoskich lat 1434-177060 oraz Pierwsze miesiace okupacji hitlerowskiej w Bydgoszczy ${ }^{61}$, przygotowane wspólnie z Włodzimierzem Jastrzębskim. W badaniach archiwistycznych nie podejmował problemów teoretycznych ani metodycznych. Skupiał się na archiwoznawstwie, stąd w jego dorobku znaleźć można przede wszystkim pra-

\footnotetext{
${ }^{56}$ Swoje wojenne losy Esman dokładnie opisał w wydanych w 2007 r. wspomnieniach. Zob. Tadeusza Esmana wspomnienia, s. 439-469.

${ }^{57}$ T. Esman, Bydgoszcz na tle wypadków 1846 r., „Arkona” 1947, nr 5-6, s. 10-11; 1947, nr 7, s. 19.

58 Tenże, Esman Józef, [w:] Polski słownik biograficzny, t. 6, pod red. nacz. W. Konopczyńskiego, Kraków 1948, s. 296-297.

${ }^{59}$ Tenże, Kilka uwag o badaniu historii Bydgoszczy, [w:] Bydgoszcz. Historia, kultura, życie gospodarcze, Gdynia 1959, s. 60-61.

${ }^{60}$ Statuty i przywileje cechów bydgoskich z lat 1434-1779, wyd. T. Esman, Z. Guldon, Bydgoszcz-Łódź 1963.

${ }^{61}$ Pierwsze miesiace okupacji hitlerowskiej w Bydgoszczy w świetle źródeł niemieckich, wyd. T. Esman, W. Jastrzębski, Bydgoszcz-Poznań 1967.
} 
ce poświęcone historii i zasobowi bydgoskich archiwów, pisane i wydawane już od 1946 r. ${ }^{62}$

Przez całe życie angażował się obywatelsko. Przed wojną należał do Towarzystwa Obrony Kresów Zachodnich, potem Polskiego Związku Zachodniego. Po 1945 r. działał w Towarzystwie Rozwoju Ziem Zachodnich. Politycznie związany ze Stronnictwem Demokratycznym był radnym Wojewódzkiej Rady Narodowej w Bydgoszczy i tamtejszej Miejskiej Rady Narodowej.

Esman zmarł 16 września 1987 r.

\section{Bydgoscy kierownicy na tle kolegów $\mathrm{z}$ innych archiwów terenowych}

Wśród kadry kierowniczej terenowych archiwów państwowych lat 1918-1939 Białynia-Rzepecki i Esman należeli do najmniej licznej grupy urzędników wywodzących się z byłego zaboru pruskiego. Oprócz nich z Wielkopolski pochodził jedynie dyrektor poznańskiego archiwum i jednocześnie pierwszy szef WAP Józef Paczkowski. Nieco bardziej liczna była grupa kierowników pochodzących z Galicji, najliczniejsza - z Królestwa Polskiego i wschodnich województw przedrozbiorowej Rzeczpospolitej. Odpowiadało to rozmieszczeniu archiwów na terytorium międzywojennej Polski ${ }^{63}$, bo szefami placówek na terytoriach byłych zaborów zostawali zazwyczaj archiwiści z nich pochodzący ${ }^{64}$. Co prawda zdarzało się, że przedwojenni pracownicy archi-

${ }^{62}$ T. Esman, Akta zachodnio-pruskich registratur Komisji Generalnej w Bydgoszczy jako źródto do dziejów wsi Pomorza Gdańskiego, "Zapiski Historyczne” 1956, t. 22, nr 1-3, s. 232-248; tegoż, Archiwum Państwowe w Bydgoszczy, "Dzisiejsze Pomorze" 1946, nr 10(24), s. 1-4; tegoż, Archiwum Państwowe w Bydgoszczy, "Zapiski Towarzystwa Naukowego w Toruniu" 1947, t. 13, z. 1-4, s, 73-78; tegoż, [Archiwum Państwowe w Bydgoszczy], „Roczniki Dziejów Społecznych i Gospodarczych" 1954, t. 13, s. 438-440; tegoż, Dzieje archiwum miejskiego, [w:] Bydgoszcz. Historia, s. 283-294; tegoż [i in.], Wojewódzkie Archiwum Państwowe w Bydgoszczy, "Archiwalny Biuletyn Informacyjny" 1954.

${ }^{63} \mathrm{~W}$ Wielkopolsce znajdowało się w zasadzie jedno archiwum państwowe, w Poznaniu, z oddziałem w Bydgoszczy. W Galicji działały początkowo trzy archiwa podległe WAP: Archiwum Ziemskie w Krakowie, Archiwum Ziemskie we Lwowie i Archiwum Państwowe we Lwowie; od 1933 r. ich liczba zmniejszyła się do dwóch, nazywanych od 1936 r. Archiwum Państwowym w Krakowie i Archiwum Państwowym we Lwowie. Na terytorium Królestwa Polskiego i ziem zabranych funkcjonowało początkowo - poza archiwami warszawskimi - dziesięć archiwów (w Grodnie, Kielcach, Lublinie, Piotrkowie, Płocku, Radomiu, Wilnie, Kaliszu, Łomży, Suwałkach), z których w 1930 r. pozostało siedem (po likwidacji placówek w Kaliszu, Łomży i Suwałkach). Por. I. Mamczak-Gadkowska, dz. cyt., s. 101-115.

${ }^{64}$ Wyjątkiem był Adam Próchnik, który urodził się we Lwowie, a został kierownikiem Archiwum Państwowego w Piotrkowie. 


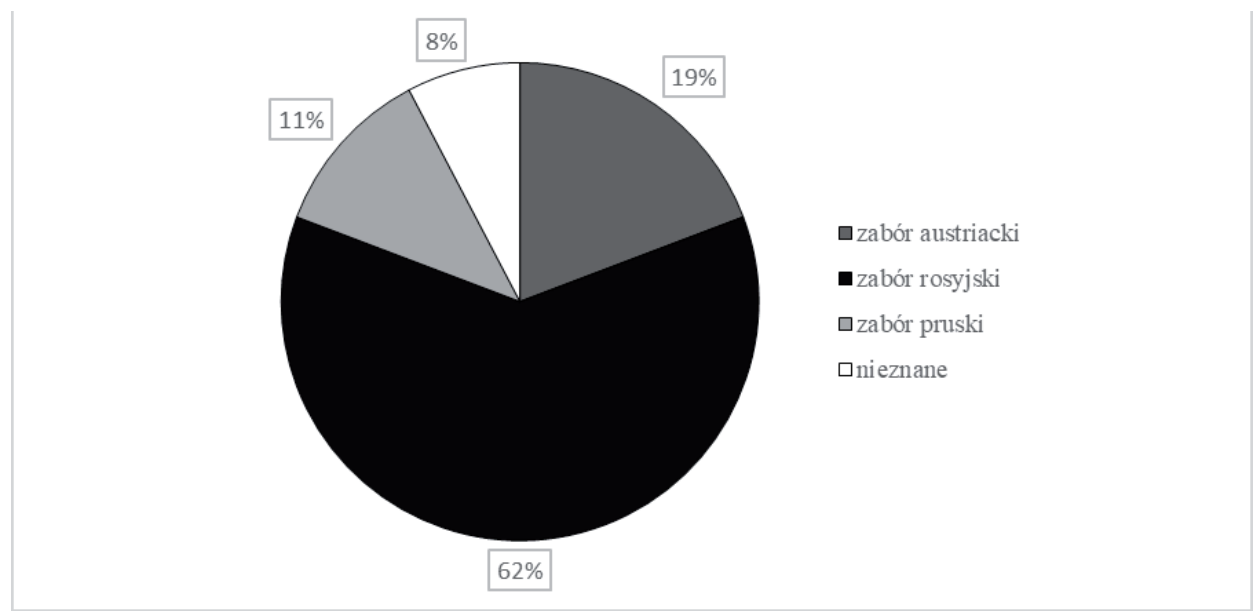

Wykres 1. Pochodzenie geograficzne kierowników terenowych archiwów państwowych w okresie międzywojennym

wów przenosili z jednej instytucji do drugiej ${ }^{65}$, jednak do rzadkości należeli zatrudniani np. i w archiwach Kongresówki, i byłej dzielnicy Pruskiej. Na stanowiskach kierowników, ewentualnie urzędników pełniących obowiązki kierownicze, znamy tylko dwa takie przypadki: Kazimierza Kaczmarczyka i Leona Białkowskiego. Pierwszy z nich przed 1939 r. pracował najpierw w Archiwum Akt Dawnych m. Krakowa, następnie w Archiwum Skarbowym w Warszawie, wrócił do Krakowa i wiosną 1920 r. trafił do Poznania, gdzie najpierw był zastępcą, a od 1925 r. kierownikiem archiwum. Drugi organizował najpierw archiwum w Kaliszu, potem trafił do Poznania, by w 1926 r. objąć stanowisko kierownika Archiwum Państwowego w Lublinie.

Białynię-Rzepeckiego i Esmana różniło pochodzenie społeczne. Pierwszy z bydgoskich archiwistów należał do najliczniejszej ${ }^{66}$ wśród personelu kierowniczego grupy pochodzenia ziemiańskiego, podczas gdy Esman - jedyny - wywodził się z rodziny rzemieślnika. Podobnym do niego wyjątkiem z tym, że pochodzącym z rodziny robotniczej - był Ignacy Świątkowski, syn maszynisty kolejowego z Sosnowca.

${ }^{65} \mathrm{~Np}$. Władysław Prawdzik był kierownikiem archiwum w Łomży, potem archiwistą w Archiwum Akt Dawnych w Warszawie, wreszcie ponownie kierownikiem w archiwach płockim i radomskim; Adam Próchnik - kierownik Archiwum Państwowego w Piotrkowie, potem pracownik AAD; Marian Witkowski zatrudniony najpierw w Archiwum Skarbowym w Warszawie, potem szef archiwum płockiego, Ferdynand Krone - kierownik najpierw Archiwum Państwowego w Kielcach, potem w Radomiu.

${ }^{66}$ Ustalenia $\mathrm{w}$ tym zakresie mogą budzić wątpliwości. Jedynie w przypadku czternastu kierowników terenowych archiwów państwowych ich biogramy podają pochodzenie społeczne. Por. wykres 2. 


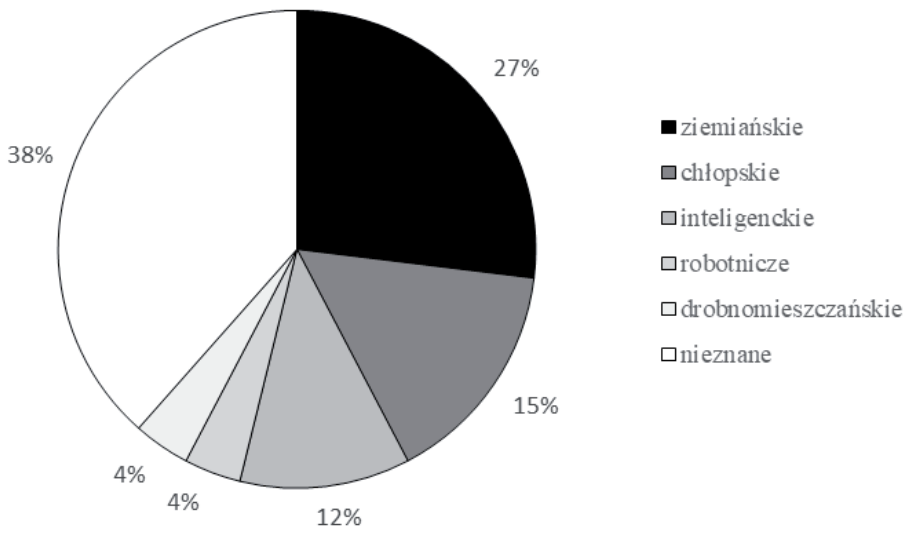

Wykres 2. Pochodzenie społeczne kierowników przedwojennych terenowych archiwów państwowych

Bydgoscy kierownicy należeli do dwóch różnych generacji archiwistów, zarówno z racji wieku, jak i doświadczenia zawodowego. Zaczynając pracę w oddziale poznańskiego.

Archiwum Państwowego, Białynia-Rzepecki miał 62 lata, a nieco starsi od niego u progu państwowej kariery archiwalnej byli jedynie Welamin Rutski ${ }^{67}$ i Stanisław Ptaszycki ${ }^{68}$. Bydgoski archiwista miał także za sobą pewne doświadczenie zawodowe w AKG. Nie był w tym zakresie wyjątkiem, choć należał do mniejszości późniejszych kierowników ${ }^{69}$. Tymczasem Esman był jednym z najmłodszych kierowników. Zaczynając pracę w bydgoskim oddziale, miał jedynie 24 lata, podobnie jak Władysław Prawdzik obejmujący stanowisko szefa łomżyńskiego archiwum państwowego. Tak jak on, doświadczenia na stanowisku kierowniczym zaczął zbierać jeszcze przed ukończeniem studiów.

Jak wspomnieliśmy wcześniej, nie wiemy wiele o wykształceniu Białyni-Rzepeckiego, który najprawdopodobniej zakończył edukację na gimnazjum i maturze. Należał w ten sposób do zdecydowanie mniej licznej grupy kierowników, którzy nie zdobyli pełnego wykształcenia wyższego. Oprócz niego należała do niej jedynie szóstka urzędników: Józef Głazek, Janina Kozłowska-Studnicka, Wacław Gizbert-Studnicki, Czesław Milewski, Ignacy Świątkow-

${ }^{67}$ Kierownik AP w Płocku miał w 1919 r. 64 lata.

${ }^{68}$ Obejmując stanowisko kierownika lubelskiego archiwum, Ptaszycki miał lat 65.

${ }^{69}$ Przed 1918 r., oprócz Białyni-Rzepeckiego w archiwach różnych typów pracowali: Józef Paczkowski, Wacław Gizbert-Studnicki, Janina Kozłowska-Studnicka, Oswald Balzer, Eugeniusz Barwiński, Franciszek Duda, Kazimierz Kaczmarczyk. Do tej grupy doświadczonych archiwistów można zaliczyć także Ptaszyckiego, który w latach 1884-1887 w Archiwum Senatu Rządzącego w Petersburgu opiekował się Metryką Koronną. 


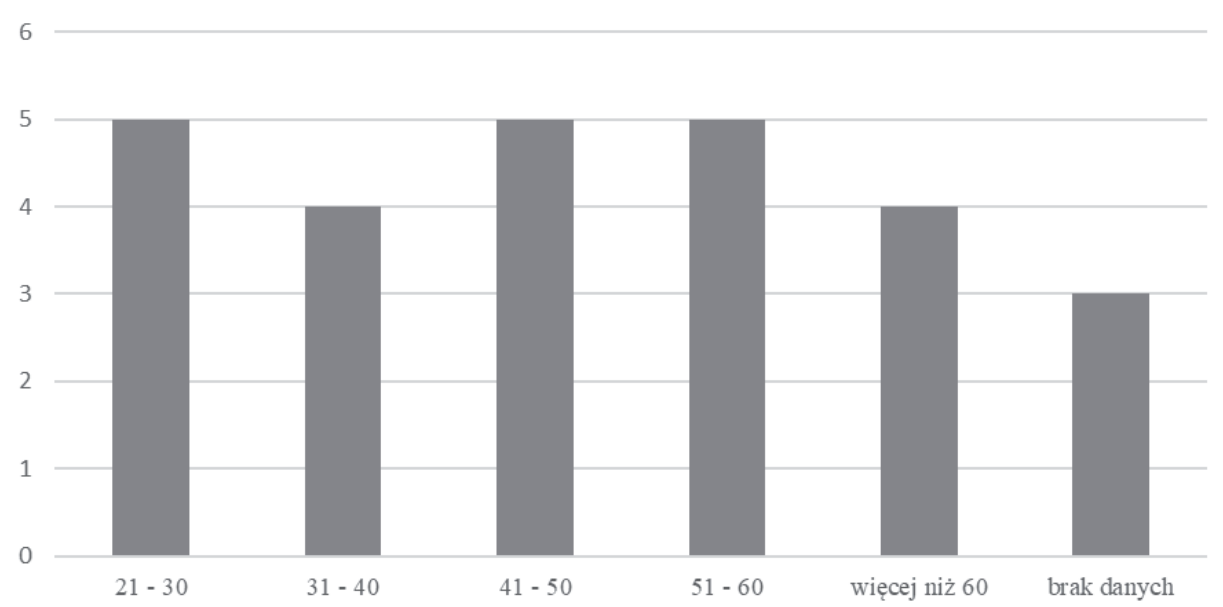

Wykres 3. Wiek archiwstów w chwili objęcia stanowiska kierowniczego (ew. p.o. kierownika) w archiwum odrodzonej Polski

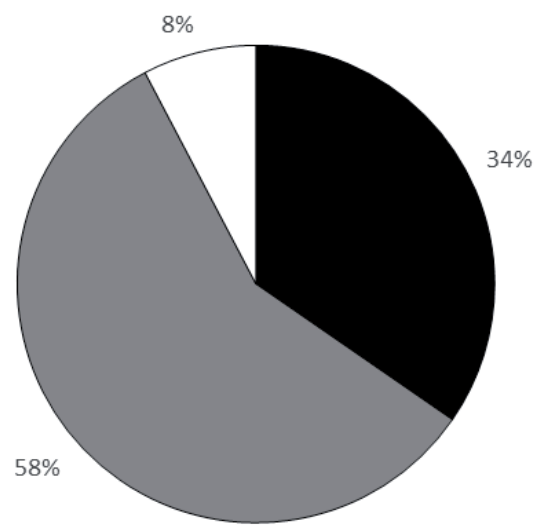

- zatrudnieni w archiwach przed $1918 \mathrm{r}$.

口zatrudninie po odzyskaniu niepodległości

$\square$ brak danych

Wykres 4. Doświadczenie zawodowe kierowników przedwojennych terenowych archiwów państwowych

ski i Stefan Zgliczyński. Pierwszy ukończył jedynie szkołę powszechną, druga - jak napisała Jadwiga Karwasińska - „przeprowadziła je [studia] samodzielnie w Petersburgu w wielkich bibliotekach w latach 1907-1911"70, trzeci ukończył studia humanistyczne w Bazylei, jednak bez dyplomu ${ }^{71}$, a ostatnia

${ }^{70}$ J. Karwasińska, dz. cyt., s. 114. Można zatem przyjąć, że Kozłowska-Studnicka zdobyła wykształcenie średnie i do tej grupy, wraz z Białynią-Rzepeckim została przez nas zaliczona (por. wykres 5).

${ }^{71}$ M. Ryńca, W. Suleja, dz. cyt., s. 121. 


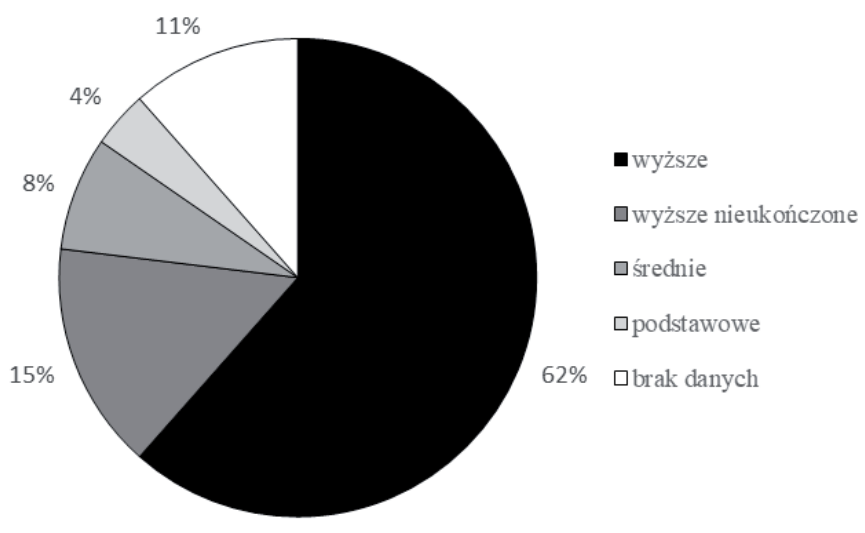

Wykres 5. Wykształcenie kierowników przedwojennych terenowych archiwów państwowych

trójka studia podjęła, jednak z różnych powodów ich nie ukończyła. Esman inaczej niż Białynia-Rzepecki - należał do większości, która legitymowała się uniwersyteckimi dyplomami w zakresie historii. To właśnie wykształcenie historyczne było najpopularniejsze wśród późniejszych kierowników terenowych archiwów państwowych i zdobywali je nawet, jeśli - jak Eugeniusz Barwiński, Leon Białkowski czy Welamin Rutski - zaczynali edukację na innych kierunkach. Oczywiście, w grupie kierowników z wyższym wykształceniem były wyjątki. Jednym z nich był Stanisław Ptaszycki, który ukończył studia filologiczne. Ludwik Bazylewski zdobył dyplom na Wydziale Inżynieryjno-Mechanicznym Politechniki Ryskiej, a Józef Raciborski-Rawita i Józef Rokoszny byli teologami.

Podobnie jak w przypadku wykształcenia, niewiele wiemy o działalności naukowej Białyni-Rzepeckiego. Natomiast Esman przejawiał pewną aktywność w tym zakresie, choć nie publikował na łamach jedynego wówczas czasopisma archiwistycznego, czyli "Archeionu”. Obaj bydgoszczanie nie byli wyjątkiem, bo niemal co drugi z szefów przedwojennych archiwów terenowych nie był aktywny naukowo ${ }^{72}$. Wyjątkami byli przede wszystkim pracownicy archiwów dużych i mieszczących się w ośrodkach uniwersyteckich. Trudno nie pamiętać o dorobku naukowym Oswalda Balzera, Eugeniusza Barwińskiego, Leona Białkowskiego, Kazimierza Kaczmarczyka, Ryszarda Mienickiego, Józefa Paczkowskiego czy Stanisława Ptaszyckiego. Spośród kierowników archiwów w mniejszych ośrodkach dorobkiem drukowanym -

${ }^{72}$ Do grupy tej zaliczyliśmy także Władysława Prawdzika, który cztery teksty opublikował na łamach "Archeionu” po II wojnie światowej. 


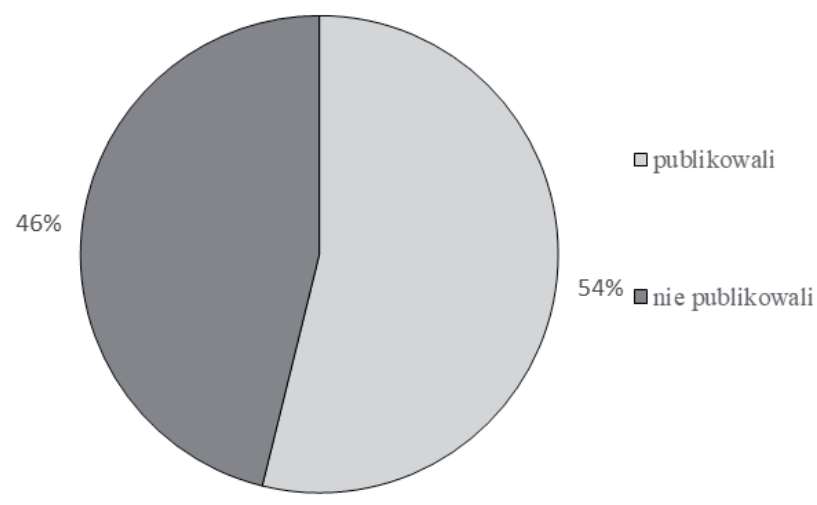

Wykres. 6. Aktywność publikacyjna przedwojennych terenowych archiwów państwowych

niekoniecznie archiwistycznym - pochwalić mogli się m.in. Janina Kozłowska-Studnicka ${ }^{73}$, Józef Raciborski-Rawita ${ }^{74}$ i Józef Rokoszny ${ }^{75}$.

Brak publikowanych wyników prac badawczych nie oznacza, że szefowie terenowych archiwów nie angażowali się zbytnio w prace naukowe. Co oczywiste, za mające taki charakter można uznać większość prac archiwalnych, które podejmowali w prowadzonych przez siebie archiwach. Byli także aktywnymi uczestnikami społecznego ruchu naukowego. Znaczna ich grupa, tak jak Esman, współtworzyła PTH i jego terenowe struktury. Działała także w lokalnych towarzystwa naukowych takich jak Towarzystwo Naukowe Płockie, Kieleckie Towarzystwo Naukowe, Towarzystwo Przyjaciół Nauk w Wilnie, poznańskie i lubelskie towarzystwa przyjaciół nauk.

${ }^{73}$ J. Kozłowska-Studnicka, Materiaty do sprawy Michała Wołtowicza 1833 r., "Ateneum Wileńskie" 1923, z. 3-4, s. 540-568; tejże, Zabory mienia Uniwersytetu Wileńskiego przez Rosje (1832-1842), [w:] Pamiętnik IV Powszechnego Zjazdu Historyków Polskich w Poznaniu 6-8 grudnia 1925 r., t. I: Referaty, Lwów 1925, Sekcja III, s. 1-5, 1 nlb; tejże, Katalog rękopisów polskich (poezyj), wywiezionych niegdyś do Cesarskiej Biblioteki Publicznej, znajdujacych się obecnie w Bibliotece Uniwersyteckiej w Warszawie, Kraków 1929; tejże, Likwidacja Uniwersytetu Wileńskiego w świetle korespondencji urzędowej, [w:] Księga pamiątkowa ku uczczeniu CCCL rocznicy założenia i X wskrzeszenia Uniwersytetu Wileńskiego, t. 1: Z dziejów dawnego uniwersytetu, Wilno 1929, s. 405-419; tejże, Rzut oka na grodzieńskie materiaty o powstaniu listopadowem, „Archeion” 1930, t. 8, s. 147-162.

${ }^{74}$ Zidentyfikowane publikacje Raciborskiego-Rawity pochodzą z czasów przed i po jego kierowniczym epizodzie w kaliskim Archiwum Państwowym. J. Raciborski, Monografja Kalisza, cz. 1, Kalisz 1912; tegoż, Dawny ratusz łódzki, „Rocznik Łódzki” 1928, t. 1, s. 191-212; tegoż, Bibljografja Łodzi, za lata 1928-1929-1930, „Rocznik Łódzki” 1931, t. 2, s. 419-507; tegoż, Bibljografja Łodzi za lata 1931-1932, „Rocznik Łódzki” 1933, t. 3, s. 355-418. Raciborski-Rawita publikował także sprawozdania z działalności Archiwum Akt Dawnych m. Łodzi na łamach „Rocznika Łódzkiego”.

75 Zob. m.in.: J. Rokoszny, Karol Frycz, Warszawa 1913; tegoż, Pamiątki Sandomierza. Ludzie i rzeczy, b.m.w. 1913; tegoż, W sprawie archiwów biur urzędowych, [w:] Pamiętnik IV Powszechnego Zjazdu Historyków Polskich w Poznaniu, Sekcja VI B, s. 2. 


\section{Zakończenie}

Kadra kierownicza terenowych archiwów państwowych w Polsce okresu międzywojennego nie była reprezentowana przez jeden model archiwisty-urzędnika. Można stwierdzić, że była w pewnym sensie odzwierciedleniem powstającego po 123 latach niewoli państwa polskiego. Państwa, w którym na każdym kroku widoczne były zaborowe odmienności, z biegiem lat coraz bardziej niwelowane. Białynia-Rzepecki i Esman jako kierownicy tej samej placówki archiwalnej na przestrzeni piętnastu lat reprezentowali dwa dosyć zróżnicowane zawodowe charaktery. Białynia-Rzepecki pierwszy kierował oddziałem bydgoskim APP przez niecałe cztery lata. Zapewne brak wyższego wykształcenia, wieloletnia praca w urzędzie na stanowisku referenta, w końcu również przywiązanie do sztywnych zasad pruskiego biurokratyzmu nie sprzyjały jego aktywności na ściśle naukowo-archiwalnym polu. Zapewne w pierwszej kolejności czuł się urzędnikiem, aniżeli archiwistą, co również przekładało się na prace prowadzonej przez niego placówki. Zupełnie innym typem na stanowisku kierownika archiwum był Esman. Można powiedzieć, że reprezentował on nową, młodą i ożywczą dla polskiej archiwistyki siłę. Młodszy od Białyni-Rzepeckiego o ponad 40 lat, jako piętnastolatek był już obywatelem wolnej Polski. Ukończone studia historyczne, działalność naukowa połączona z praktyką archiwalną jeszcze w czasie studiów, dały Esmanowi mocne podstawy do wprowadzenia bydgoskiego archiwum w krąg tych państwowych archiwów, które wykazywały się dużą aktywnością w zakresie chociażby opracowania zasobu, udostępniania materiałów czy wykonywania kwerend. Nie ulega jednak wątpliwości, że obaj kierownicy - Białynia-Rzepecki i Esman - ukonstytuowali bydgoskie archiwum w ramach międzywojennej sieci archiwów państwowych. Pierwszy z nich archiwum to zorganizował i urządził, drugi wprowadził na tory współczesnej, jak na ówczesne czasy, działalności naukowo-archiwalnej.

\section{Bibliografia}

\section{Archiwalia}

Archiwum Państwowe w Bydgoszczy:

Akta miasta Bydgoszczy 1559-1945 [1946-1950], seria Zarząd Miejski w Bydgoszczy 19201939, Kartoteka ewidencji ludności.

Archiwum Państwowe w Poznaniu Oddział w Bydgoszczy 1924-1939, sygn. 3, 4a, 11, 39, 62.

Wojewódzkie Archiwum Państwowe w Bydgoszczy [1938] 1945-1983, sygn. 113, 121.

Archiwum dr Anny Perlińskiej dyrektora Archiwum Państwowego w Bydgoszczy [1903] 1921-2005, sygn. 253.

Spuścizny i kolekcje rodzinne w Archiwum Państwowym w Bydgoszczy - zbiór szczątków zespołów 1769-2015, sygn. 366.

Archiwum zakładowe AP w Bydgoszczy, sygn. 2/54. 
Archiwum Państwowe w Poznaniu:

Akta miasta Poznania 1254-1945, sygn. 14385.

Archiwum Uniwersytetu im. Adama Mickiewicza w Poznaniu: sygn. $103 \mathrm{~b} / 577$.

Biblioteka Kórnicka PAN:

Teki Dworzaczka, reg. 59315-59317, 59319 i 59330, http://teki.bkpan.poznan.pl/index_ regesty.html (dostęp: 25.09.2019).

\section{Literatura}

Archiwum Państwowe w Poznaniu w latach 1919-1926, Kronika, pod red. W. Łopacińskiego, „Archeion" 1928, t. 4, s. 145-161.

Bielińska M., Balzer Oswald, [w:] Stownik biograficzny archiwistów polskich, t. I: 1918-1984, pod red. M. Bielińskiej, I. Janosz-Biskupowej, Warszawa-Łódź 1988, s. 29-30.

Cieślak F., Białkowski Leon, [w:] Stownik biograficzny archiwistów polskich, t. I: 1918-1984, pod red. M. Bielińskiej, I. Janosz-Biskupowej, Warszawa-Łódź 1988, s. 37-39.

Degen R., Syta K., Archiwum byłej Komisji Generalnej dla Wielkopolski i Pomorza w latach 1920-1924. Przyczynek do genezy bydgoskiego archiwum państwowego [w druku].

Deruga A., Sprawozdanie z działalności Koła Historyków Stuchaczy USB w Wilnie w latach 19231933, [w:] Ksiega pamiątkowa Koła Historyków Stuchaczy Uniwersytetu Stefana Batorego w Wilnie 1923-1933, Wilno 1933, s. 355-367.

Esman T., Akta zachodnio-pruskich registratur Komisji Generalnej w Bydgoszczy jako źródło do dziejów wsi Pomorza Gdańskiego, „Zapiski Historyczne” 1956, t. 22, nr 1-3, s. 232-248.

Esman T., Archiwum Państwowe w Bydgoszczy, „Dzisiejsze Pomorze” 1946, nr 10(24), s. 1-4.

Esman T., Archiwum Państwowe w Bydgoszczy, "Zapiski Towarzystwa Naukowego w Toruniu" 1947, t. 13, z. 1-4, s. 73-78.

Esman T., [Archiwum Państwowe w Bydgoszczy], „Roczniki Dziejów Społecznych i Gospodarczych" 1954, t. 13, s. 438-440.

Esman T., Bydgoszcz na tle wypadków 1846 r., „Arkona” 1947, nr 5-6, s. 10-11; 1947, nr 7, s. 19.

Esman T., Dzieje archiwum miejskiego, [w:] Bydgoszcz. Historia, kultura, życie gospodarcze, Gdynia 1959, s. 283-294.

Esman T., Esman Józef, [w:] Polski stownik biograficzny, t. 6, pod red. nacz. W. Konopczyńskiego, Kraków 1948, s. 296-297.

Esman T., Jan Wilhelm Kassyusz. Zarys biografii na tle życia Wielkopolski w pierwszej połowie XIX wie$k u$, „Strażnica Zachodnia” 1926, r. 5, nr 1, s. 28-61.

Esman T., Kilka uwag o badaniu historii Bydgoszczy, [w:] Bydgoszcz. Historia, kultura, życie gospodarcze, Gdynia 1959, s. 60-61.

Esman T., Uzupetnienie życiorysu Jana Wilhelma Kassyusza, „Kronika Miasta Poznania” 1938, r. 16, nr 2, s. 186-199.

Esman T. [i in.], Wojewódzkie Archiwum Państwowe w Bydgoszczy, „Archiwalny Biuletyn Informacyjny" 1954.

Guldon R, Bazylewski Ludwik, [w:] Stownik biograficzny archiwistów polskich, t. II: 1906-2001, pod red. B. Woszczyńskiego, Warszawa 2002, s. 32-33.

Guldon R., Głazek Józef Lucjan, [w:], Stownik biograficzny archiwistów polskich, t. II: 1906-2001, pod red. B. Woszczyńskiego, Warszawa 2002, s. 54.

Kamiński A., Barwiński Eugeniusz, [w:] Słownik biograficzny archiwistów polskich, t. I: 1918-1984, pod red. M. Bielińskiej, I. Janosz-Biskupowej, Warszawa-Łódź 1988, s. 34-36.

Kamiński A., Duda Franciszek, [w:] Stownik biograficzny archiwistów polskich, t. I: 1918-1984, pod red. M. Bielińskiej, I. Janosz-Biskupowej, Warszawa-Łódź 1988, s. 56-57.

Karwasińska J., Kozłowska-Studnicka Janina, [w:] Stownik biograficzny archiwistów polskich, t. I: 1918-1984, pod red. M. Bielińskiej, I. Janosz-Biskupowej, Warszawa-Łódź 1988, s. 114-116.

Kisiel H., Prawdzik Wtadystaw, [w:] Stownik biograficzny archiwistów polskich, t. I: 1918-1984, pod red. M. Bielińskiej, I. Janosz-Biskupowej, Warszawa-Łódź 1988, s. 174-175. 
Kozłowska-Studnicka J., Katalog rękopisów polskich (poezyj), wywiezionych niegdyś do Cesarskiej Biblioteki Publicznej, znajdujących się obecnie w Bibliotece Uniwersyteckiej w Warszawie, Kraków 1929.

Kozłowska-Studnicka J., Likwidacja Uniwersytetu Wileńskiego w świetle korespondencji urzędowej, [w:] Ksiegga pamiątkowa ku uczczeniu CCCL rocznicy założenia $i$ X wskrzeszenia Uniwersytetu Wileńskiego, t. 1: Z dziejów dawnego uniwersytetu, Wilno 1929, s. 405-419.

Kozłowska-Studnicka J., Materiały do sprawy Michata Wołtowicza 1833 r., "Ateneum Wileńskie” 1923, z. 3-4, s. 540-568.

Kozłowska-Studnicka J., Rzut oka na grodzieńskie materiaty o powstaniu listopadowem, "Archeion” 1930 , t. 8, s. 147-162.

Kozłowska-Studnicka J., Zabory mienia Uniwersytetu Wileńskiego przez Rosję (1832-1842), [w:] Pamiętnik IV Powszechnego Zjazdu Historyków Polskich w Poznaniu 6-8 grudnia 1925 r., t. I: Referaty, Lwów 1925, Sekcja III, s. 1-5, 1 nlb.

Kotewicz R. i red., Próchnik Adam Feliks, [w:] Stownik biograficzny archiwistów polskich, t. II: 19062001, pod red. B. Woszczyńskiego, Warszawa 2002, s. 149-151.

Kotewicz R. i red., Świątkowski Ignacy, [w:] Słownik biograficzny archiwistów polskich, t. II: 19062001, pod red. B. Woszczyńskiego, Warszawa 2002, s. 182.

Kutta J., Biatynia-Rzepecki Mieczystaw (1962-1927), archiwista, [w:] Bydgoski stownik biograficzny, pod red. J. Kutty, Bydgoszcz 1994, s. 28-29.

Kutta J., Essman (Esman) Tadeusz Antoni (1903-1987), historyk, archiwista, działacz społeczny, [w:] Bydgoski stownik biograficzny, pod red. J. Kutty, Bydgoszcz 1994, s. 43-45.

Kwiatek J., Spór o model gimnazjum w XIX-wiecznej niemieckiej myśli pedagogicznej, „Cieszyński Almanach Pedagogiczny" 2012, nr 1, s. 36-62.

Makowska A., Ryszewski B., Zarys dziejów Archiwum Państwowego w Kielcach (Z okazji czterdziestolecia), "Archeion” 1963, t. 39, s. 45-62.

Małachowski M., Królewskie Gimnazjum Fryderyka Wilhelma, [w:] Encyklopedia Bydgoszczy, t. 2, pod red. W. Jastrzębskiego, Bydgoszcz 2017, s. 301-302.

Małachowski E., Miejskie Gimnazjum Realne, [w:] Encyklopedia Bydgoszczy, t. 2, pod red. W. Jastrzębskiego, Bydgoszcz 2017, s. 311.

Mamczak-Gadkowska I., Archiwa państwowe w II Rzeczypospolitej, Poznań 2006.

Mamczak-Gadkowska I., Paczkowski Józef, [w:] Stownik biograficzny archiwistów polskich, t. I: 19181984, pod red. M. Bielińskiej, I. Janosz-Biskupowej, Warszawa-Łódź 1988, s. 161-164.

Papierowski J., Stefański J., Płocczanie znani i nieznani. Słownik biograficzny, t. II, Płock 2007, s. 151, 724.

Perlińska A., Białynia-Rzepecki Mieczystaw, [w:] Stownik biograficzny archiwistów polskich, t. I: 19181984, pod red. M. Bielińskiej, I. Janosz-Biskupowej, Warszawa-Łódź 1988, s. 39-40.

Piekarski T., Rutski Welamin Stefan, [w:] Stownik biograficzny archiwistów polskich, t. III: 1835-2015, pod red. E. Rosowskiej, Warszawa 2017, Warszawa 2017, s. 209.

Pierwsze miesiące okupacji hitlerowskiej w Bydgoszczy w świetle źródeł niemieckich, wyd. T. Esman, W. Jastrzębski, Bydgoszcz-Poznań 1967.

Pogorzelska I., Historia Archiwum Państwowego w Kielcach, „Świętokrzyskie Studia Archiwalno-Historyczne" 2012, t. 1, s. 17-34.

Pogorzelska I., 90 lat Archiwum Państwowego w Kielcach, „Z Dziejów Miasta i Regionu. Rocznik Oddziału PTH w Skarżysku-Kamiennej" 2014, r. 5, s. 83-106.

Raciborski J., Bibljografja Łodzi, za lata 1928-1929-1930, „Rocznik Łódzki” 1931, t. 2, s. 419-507.

Raciborski J., Bibljografja Łodzi za lata 1931-1932, „Rocznik Łódzki” 1933, t. 3, s. 355-418.

Raciborski J., Dawny ratusz tódzki, „Rocznik Łódzki” 1928, t. 1, s. 191-212.

Raciborski J., Monografja Kalisza, cz. 1, Kalisz 1912.

Radtke I., Kaczmarczyk Kazimierz, [w:] Stownik biograficzny archiwistów polskich, t. I: 1918-1984, pod red. M. Bielińskiej, I. Janosz-Biskupowej, Warszawa-Łódź 1988, s. 93-95.

Radziwonowicz T., O powstaniu i działalności Archiwum Państwowego w Suwałkach (1921-1926), „Rocznik Augustowsko-Suwalski” 2006, t. 6, s. 65-75. 
Rokoszny J., Karol Frycz, Warszawa 1913.

Rokoszny J., Pamiątki Sandomierza. Ludzie i rzeczy, b.m.w. 1913.

Rokoszny J., W sprawie archiwów biur urzędowych, [w:] Pamiętnik IV Powszechnego Zjazdu Historyków Polskich w Poznaniu 6-8 grudnia 1925 r., t. I: Referaty, Lwów 1925, Sekcja VI B, s. 2.

Romaniuk M., Esman Tadeusz, [w:] Stownik biograficzny archiwistów polskich, t. III: 1835-2015, pod red. E. Rosowskiej, Warszawa 2017, s. 70-72.

Ryńca M., Suleja W., Studnicki (Gizbert-Studnicki) Wactaw, [w:] Polski stownik biograficzny, t. 45, pod red. nacz. A. Romanowskiego, Warszawa-Kraków 2007, s. 121-125.

Sekcja VII. Nauczanie historii, [w:] Pamiętnik IV Powszechnego Zjazdu Historyków Polskich w Poznaniu 6-8 grudnia 1925 r. Protokoły, wyd. K. Tyszkowski, Lwów 1927, s. 147-152.

Sierocka-Pośpiech M., Milewski Czesław, [w:] Stownik biograficzny archiwistów polskich, t. III: 18352015, pod red. E. Rosowskiej, Warszawa 2017, s. 153-154.

Sprawozdanie z działalności archiwów państwowych. Rok 1927, red. W Łopaciński, „Archeion” 1929, t. 5, s. 44 (Działu Urzędowego).

Sprawozdanie z działalności archiwów państwowych Rok 1928, red. W. Łopaciński, "Archeion” 1930, t. 6-7, s. 31, 41-42, 55 (Działu Urzędowego).

Statuty i przywileje cechów bydgoskich z lat 1434-1779, wyd. T. Esman, Z. Guldon, BydgoszczŁódź 1963.

Szczepaniak E., Witkowski Marian, [w:] Stownik biograficzny archiwistów polskich, t. II: 1906-2001, pod red. B. Woszczyńskiego, Warszawa 2002, s. 193.

Tadeusz Esman (1903-1987), „Kalendarz Bydgoski na rok 1989”, r. 22, s. 186-187.

Tadeusza Esmana wspomnienia o Bydgoszczy, cz. 1, wybór i oprac. J. Esman, M. Romaniuk, „Kronika Bydgoska" 2007, t. 29, s. 429-469.

Tomczak A., Mienicki Ryszard, [w:] Stownik biograficzny archiwistów polskich, t. I: 1918-1984, pod red. M. Bielińskiej, I. Janosz-Biskupowej, Warszawa-Łódź 1988, s. 144-146.

Trojanowska M., Ptaszycki Stanistaw, [w:] Stownik biograficzny archiwistów polskich, t. I: 1918-1984, pod red. M. Bielińskiej, I. Janosz-Biskupowej, Warszawa-Łódź 1988, s. 178-180.

Wasiak J., Raciborski-Rawita Józef, [w:] Stownik biograficzny archiwistów polskich, t. I: 1918-1984, pod red. M. Bielińskiej, I. Janosz-Biskupowej, Warszawa-Łódź 1988, s. 183-184.

Wójcik W., Rokoszny Józef ks., [w:] Słownik biograficzny archiwistów polskich, t. I: 1918-1984, pod red. M. Bielińskiej, I. Janosz-Biskupowej, Warszawa-Łódź 1988, s. 185-186.

Wykaz członków IV. Powszechnego Zjazdu Historyków Polskich w Poznaniu w dniach od 6 do 8 grudnia 1925 r., [w:] Pamiętnik IV Powszechnego Zjazdu Historyków Polskich w Poznaniu 6-8 grudnia 1925 r. Protokoty, wyd. K. Tyszkowski, Lwów 1927, s. 252.

Robert Degen, Krzysztof Syta

\section{Mieczysław Białynia-Rzepecki i Tadeusz Antoni Esman Przyczynek do charakterystyki kadry kierowniczej archiwów państwowych w okresie międzywojennym}

\section{Streszczenie}

Artykuł przedstawia Mieczysława Białynię Rzepeckiego i Tadeusza Esmana, kierowników bydgoskiego oddziału Archiwum Państwowego w Poznaniu. Wykorzystano publikowane materiały biograficzne i wyniki kwerendy w archiwach Bydgoszczy i Poznania. Portrety obu archiwistów udało się nieco rozbudować, a ich aktywność umieścić na tle działalności innych kierowników międzywojennych terenowych archiwów państwowych. 
Wśród kierowników terenowych archiwów państwowych okresu międzywojennego Białynia-Rzepecki i Esman należeli do najmniej licznej grupy pochodzącej z terytorium byłego zaboru pruskiego. Reprezentowali różne generacje archiwistów. Pierwszy, jak co szósty kierownik zaczynał pracę w służbie archiwalnej po sześćdziesiątce, Esman - jak co piąty - przed trzydziestką. Różniło ich wykształcenie, które Białynia-Rzepecki zakończył prawdopodobnie na maturze, a Esman - jak większość szefów archiwów - legitymował się dyplomem uniwersyteckim w zakresie historii. Nie miało to większego wpływu na ich dorobek publikacyjny, choć Esman znalazł się wśród 54 proc. kierowników, którzy przed wojną wydali prace naukowe. Obaj bydgoszczanie, jak większość międzywojennych archiwistów, byli aktywnie społecznie i angażowali się w działalność towarzystwa naukowych.

Słowa kluczowe: archiwa państwowe w Polsce, Archiwum Państwowe w Poznaniu, Archiwum Państwowe w Bydgoszczy, kadra archiwów państwowych, kierownicy archiwów państwowych, Białynia-Rzepecki Mieczysław, Esman Tadeusz

Robert Degen, Krzysztof Syta

\title{
Mieczysław Białynia-Rzepecki and Tadeusz Antoni Esman. Managerial staff in state archives in the years 1918-1939 - an introduction
}

\begin{abstract}
Among the field managers working in state archives in the interwar period, Białynia-Rzepecki and Esman belonged to the smallest group coming from the territory of the former Prussian partition. They represented two different generations of archivists: the former started working in archival services after he had turned sixty (just like $18 \%$ of managers), while the latter (like $20 \%$ of managers) - before he turned thirty. They also had different education: Białynia-Rzepecki finished his at high school, while Esman (like most managers working in archives) had a university degree in history. This had no real impact on how many papers they published, though it was Esman who was in a group of $54 \%$ of managers who had published scientific works before the war. They both came from Bydgoszcz and like most archivists in the interwar period they were socially active and involved in the life of scientific societies.
\end{abstract}

Keywords: state archives in Poland, State Archive in Poznań, State Archive in Bydgoszcz, state archive staff, state archive management, Białynia-Rzepecki Mieczysław, Esman Tadeusz 